\title{
Implementation of Legal Theory by Notary in Exercise Its Authority
}

\author{
Mochammed Dzakhy Ariefuddin Dwi Putranda ${ }^{1}$, Wahyu Adhi \\ Admaja $^{2}$ and Ngadino $^{3}$
}

Abstract. The purpose of this study was to: 1) To find out what a notary authority. 2) To determine and analyze the correlation between the Notary Law Theory to exercise its authority.

Based on the results of data analysis concluded that: 1) Based on the duties and authority of Notary asserted in UUJN, split into three areas of authority ie general authority (Article 15 paragraph 1 UUJN), a special authority (Article 15 paragraph 2 UUJN), the authority which is to be determined (Article 15, paragraph 3 UUJN), 2) Conditions Referring to the basic acquisition of authority, that the notary in a deed relating to land comes from legislation that is under the authority attribution means authorizing the new government by a provision in the legislation which in this case is Notary Law, so authority obtained through the attribution is a genuine authority.

Keywords: Theory of Law; Notary; Authorities.

\section{Introduction}

Notary has been known in our country, since the Dutch colonized Indonesia, because the notary is an institution that is already known in their lives in their own homeland. ${ }^{4}$ The existence of the Notaries in Indonesia is always associated with the presence of the faculty of law, it is evident from the result in the institutions Notary everything from law school with a specialty Notary Education Program Specialist or the current Master of Notary. ${ }^{5}$

The existence of the Notary appear present in our country, because to achieve certainty and legal protection for members of the public. Given in the area of private law (civil), the State put Notary as a public official authorities have in terms of making authentic act, for the sake of proof or evidence. The regulation of the Notary office has begun regulated Notaries in Reglement op Het Nederlands Indie (stbl.1860: 3$)^{6}$, In 2004 diundangkanlah Act No. 30 of 2004 concerning Notary. The setting positions Notary more refined with the laws of the Republic of Indonesia Number 2 of 2014 on

\footnotetext{
${ }^{1}$ Students of Master of Notarial Law, Faculty Of Law, Universitas Islam Sultan Agung email siblehcakep@gmail.com

2 Students of Master of Law, Faculty Of Law, Universitas Islam Sultan Agung email wahyuadhiadmaja10@gmail.com

${ }^{3}$ Notaris /PPAT in Semarang

${ }^{4}$ R. Soegono Notodisoerjo, 2013, Hukum Notariat Di Indonesia Suatu Penjelasan, pbl. 2, PT.Raja Grafindo Persada, Jakarta, p 1.

5 Habib Adjie, 2009, Hukum Notaris Indonesia (Tafsir Tematik Terhadap Undang-Undang Jabatan Nomor 30 Tahun 2004 Tentang Jabatan Notaris, pbl. 2, PT.Refika Aditama, Bandung, p 1.

${ }^{6}$ Notaries in Reglement op Het Nederlands Indie (stbl.1860: 3 ) is the regulatory reform of the Notary office in Indonesia in the days of the Dutch East Indies, this regulation is the replacement of the Instruction voor de Notarissen Residerende in Ambit in Nederlands Indie.
} 
the Amendment of Act No. 30 of 2004 concerning Notary, which was approved on 17 January 2014 by the Parliament of the Republic of Indonesia (DPR-RI).

The position of a notary in Indonesia harder than the Notary in the Netherlands. Notary in Indonesia face a subscription (client) ${ }^{7}$ many kinds of population groups and each of them has its own customs. And of that a Notary is obliged to provide legal counseling beforehand that is easily understood by the subscription in the face of the Notary. ${ }^{8}$

Notary Public Officials which is the only one authorized to make an authentic deed regarding all of making agreements and determination required by the General Regulation or by the concerned desired to be stated in an authentic deed, ensure certainty the date, save the deed and give Grosse ${ }^{9}$, Copies and excerpts, all along the deed was by a general rule not also be assigned or excluded to the official or other person. ${ }^{10}$ While the changes in the Notary Law, gives the sense that the notary is a public official who is authorized to make the authentic act and have more authority as referred to in this Act or under other legislation. ${ }^{11}$ This means that the Notary deed relates directly to the value of the dignity of the parties that promise. The promises that have been stated in the deed reflects a genuine desire presented by the parties. Legal needs in the community can be seen by the increasing number of forms of agreements set forth in a notarial deed, which Notary is a public official authorized to make an authentic deed and other authorities as stipulated in the legislation. ${ }^{12}$ The authority makes this an authentic deed executed by the Notary only as far as the manufacture of certain authentic deed is not reserved for other public officials. ${ }^{13}$ It can be concluded that the Notary is the only public official who has the authority.

According to Djoko Soepadmo ${ }^{14}$, an authentic deed is a deed made in the prescribed form or according to the rules in the legislation by or before public authorities to the place where the deed was made, ${ }^{15}$ while according to Husni Thamrin, authentic deed is a deed made by an officer who is authorized to do so by the authorities in accordance with the conditions set, either with or without the assistance of the parties concerned,

\footnotetext{
${ }^{7}$ Client is defined as one who enlist the services of Legal Practitioners to take care of his case. I.P.M Ranuhandoko, 2018, Terminologi Hukum-Inggris Indonesia, pbl.5, Sinar Grafika, Jakarta, p 134.

${ }^{8}$ R. Soesanto, 2018, Tugas Kewajiban dan Hak-Hak Notaris Wakil Notaris (sementara), Pradnya Paramita, Jakarta, p 28.

${ }^{9}$ Grosee is a copy of a court or an authentic deed (notary deed) having executorial power, which means that it must wear grosse head on it the words, "As Justice Under God Almighty", as represented every verdict should wear a head verdict words that, according to article 4 Undan Act No. 14 of 1970 (LN 74 LN1970 No.2951). Victor M.Situmorang and Cormentyana Sitanggang, 1993, Grosse Akta dalam Pembuktian dan Eksekusi, Cetakan 1, Rineka Cipta, Jakarta, p 39.

${ }_{10}$ Notary Regulations, Article 1 Stb 1860-31 compiled by GHS Lumban Tobing, in Muchlis Fatahna dkk, 2003, Notaris Bicara Soal Kenegaraan, Watampone Pers, Jakarta, p 253.

${ }^{11}$ Article 1 paragraph 1 of the Act of the Republic of Indonesia Number 2 of 2014 on the Amendment of Act No. 30 of 2004 on Notary.

12 Santia Dewi and R.M Fauwas Diradja, 2011, Panduan Teori dan Praktik Notaris, Pustaka Yustika, Yogyakarta, 9.

${ }^{13}$ Habib Adjie, op.cit, Hukum Notaris Indonesia, p 40.

${ }^{14}$ Djoko Soepadmo is a Notary in Surabaya, Djoko Soepadmo also an outstanding faculty Study Program Specialist I Notary Law Faculty of Airlangga University, Surabaya.

${ }^{15}$ Djoko Soepadmo, 2014, Teknik Pembuatan Akta Seri B-1, PT.Bina Ilmu, Surabaya, p.ii
} 
which records what is sought to be loaded therein by the parties concerned, the authentic act contains information that menerangakan officials about what he did or seen dihadapnnya. ${ }^{16}$ Article 1868 Book of Civil Law states that "the authentic act is an act which is in the form prescribed by law, made by or in the presence of public servants in power to it in a place where the deed made." ${ }^{17}$ In line with the sound of article 1868 Book of Civil Law by Habib Adjie, that Article 1868 of the Civil Code imposes limits are elements of what is meant by authentic act, namely ${ }^{18}$ :

- It shall be made by the (door) or in the presence of (ten overstaan) a General Officer.

- It shall be in the form prescribed by law.

- Public Servants (Public Officers) by or before whom the deed was made, should have the authority to make such deed.

Authentic act gives a perfect evidence between the parties and the heirs and have binding force. Perfect means an authentic act is sufficient to prove an event or situation without the need for the addition of other evidence. Tying means everything is included in the certificate must be trusted and considered really happened, so if there are those who deny or doubt the truth then the party is exactly what should prove a doubt and untruth of the authentic deed. ${ }^{19}$ One more requirement that must be added to the authentic act in it has included all the elements of written evidence, witnesses, suspicions, recognition, and vows. ${ }^{20}$ Knowing the importance of the task and the position of a notary in the midst of society and the strength of evidence of an authentic deed made, it can be said that the office of Notary Public is an office of trust. Position of the trust law and society requires someone who is a Notary is responsible for implementing these beliefs with the best and uphold legal ethics, dignity and nobility of office.

Notaries often in practice involved with lawsuits either as a witness or as a suspect. ${ }^{21}$ Involvement Notaries in lawsuits due to an error in deed made, either because of errors Notary itself nor the fault of the parties or one of the parties does not give any information or document the actual (not the good faith of the parties or one party) or have there is no agreement between the Notary by one of the parties who cause harm to others. Dealing with the deed he had done, the Notary must be held accountable for their criminal cause harm to the parties or one party. ${ }^{22}$ Notary basically can not be held accountable for criminal, because the notary is accountable only to the formal deed. ${ }^{23}$

Related to the allegations because the case law made by a Notary, in Article 66 paragraph 1 of Act No. 30 of 2004 concerning Notary mention that investigator,

\footnotetext{
${ }^{16}$ Husni Thamrin, 2011, Pembuatan Akta Pertanahan Oleh Notaris, pbl. 2, Laksbang Pressindo, Yogyakarta, p.11.

${ }^{17}$ The Code of Civil Code Translation by Prof.R.Subekti SH, PT Pradnya Pramita: Jakarta, p 475. ${ }^{18} \mathrm{Habib}$ Adjie, 2011, Kebatalan dan Pembatalan Akta Notaris, PT.Refika Aditama. Bandung, p. 5

${ }^{19}$ Alexander, 2012, Bahan Kuliah Peraturan Jabatan Notaris Dan Pejabat Pembuat Akta Tanah (PPAT), Magister Kenotariatan Univeristas Andalas, Padang

${ }^{20}$ Habib Adjie, Op.cit, Kebatalan dan Pembatalan Akta Notaris, p. 6.

${ }^{21}$ Mulyoto, 2010, Kesalahan Notaris dalam Pembuatan Akta Perubahan Dasar CV, Cakrawala Media, Yogyakarta, p 2.

${ }^{22}$ Ira Koesoemawati dan Yunirman Rijan, 2009, Ke Notaris, Raih Asa Sukses (RAS), Jakarta. P.82

${ }^{23}$ Pieter Latumaten 2009, nullification and degradation Strength of Evidence Deed And Model Aktanya, paper presented at the XX Congress of Notaries Association of Indonesia in Surabaya.
} 
prosecutor, or judge, in making minuta deed and calling Notary, subject to approval of the Assembly Regional Supervising (MPD). ${ }^{24}$ Assembly Konstitus Court (MK) on March 23, 2013 has granted the request for a judicial (judicial review) of Article 66 (paragraph (1) of Act No. 30 of 2004 concerning Notary filed bro. Kant Kamal. Constitutional Court decision essentially cancel the phrase "with the consent of the Supervisory Council of Regions" in article tested. ${ }^{25}$ By Decision No. MK No. 49 / PUU-X / 2012 dated March 23, 2013 the legal proceedings involving the examination of the Notary not require the approval of the Supervisory Council of Regions (MPD) again and the phrase NRI considered contrary to the Constitution of 1945 and does not have binding legal force. ${ }^{26}$ In the trial and proceedings of the MOJ, this would mean that the decision is final and binding (final and binding). ${ }^{27}$

The task of notaries provide assistance on creating an authentic deed. And thus, it is important for notaries to be able to understand the regulations stipulated by law so that the general public who do not know or do not understand the rule of law, can be understood correctly and not doing things that are against the law. ${ }^{28}$ Certainty, order, and legal protection requires, among other things, that the traffic law in public life requires the existence of evidence which clearly define the rights and obligations of a person as a subject of law in society. Position based trust between the notary and the notary who use the services. ${ }^{29}$ Clarity in making legislation, will minimize the occurrence of multiple interpretations, in other words a clear legislation to provide legal certainty and minimize the occurrence of disputes. Legal certainty is a state where a regulation is made and enacted exactly as set out clear and logical. Obviously in the sense that there are no norms obscurity or doubt (interpretations) and logical in the sense of becoming a system of norms the other norms that do not clash or conflict norm. ${ }^{30}$ Legal certainty pointed to a clear law enforcement, remains, consistently and consequently, the implementation of which can not be influenced by circumstances subjective nature. Indicators of legal certainty in a country itself is the presence of clear legislation and legislation is implemented well by the judges and other judicial officers. ${ }^{31}$ Based on the above, the authors are interested to do the writing with the title "Implementation Of Legal Theory By Notary In Exercise Its Authority".

\section{Research methods}

24 Habib Adjie, 2011, Kompilasi Peraturan Perundang-Undangan Jabatan Notaris,Pustaka Zaman, Semarang, p 22.

${ }^{25}$ Alwesius, 2013, Putusan Mahkamah Konstitusi Terhadap Pasal 66 UUJN dan Tindakan Yang Dapat Kita Lihat Kedepan. http://alwesius.blogspot.com/2013/05/putusan-mahkamahkonstitusiterhadap.html.

${ }^{26}$ Diah Sulistyani Muladi, 2013, Pasca Putusan MK Kalau Notaris Benar dan Taat Hukum Mengapa Resah. https://www.medianotaris.com/groups/248567705262940/.

27 Maruarar Siahaan, 2011, Hukum Acara Mahkamah Konstutisi Republik Indonesia, Ed. 2 pbl. 1, Sinar Grafika, Jakarta, p 202.

${ }^{28}$ Komar Andasasmita, Notaris Selayang Pandang, pbl. 2, (Bandung Alumni/ 1983/Bandung, 1983), p. 2.

${ }^{29}$ R. Sugondo Notodisoerjo, Hukum Notariat di Indonesia, (Jakarta: PT. Raja Grafindo, 1993), p. 13

${ }^{30}$ Peter Mahmud Marzuki, Pengantar Ilmu Hukum, Kencana Pranada Media Group, Jakarta, 2009, p. 158

${ }^{31}$ Abdul Rachmad Budiono, Pengantar Ilmu Hukum, Bayumedia Publishing, Malang, 2015, p. 22 
Volume 6 Issue 3, September 2019

The approach used in this study mainly is the approachnormative, normative is legal research done by researching library materials or secondary data as the base material to be tested by conducting a search for rules and literature relating to the cases studied.

\section{Results and Discussion}

\subsection{Authority theory}

According to the practical Indonesian dictionary compiled by the AA. Waskito, said the authority has the right meaning and power that belongs to do something. The term authority can not be equated with the term affair because the authority can be interpreted as a right and obligation to execute one or more functions of management (setting, planning, organization, management and supervision) on a particular object that is handled by the government. ${ }^{32}$ Along with the main pillars of the State ${ }^{33}$ namely the principle of legality, based on this principle implies that government authority is derived from Regulation Legislation, meaning that the source of authority for the government is Regulation Legislation. ${ }^{34}$ Power or authority is always there in every field of life, whether simple society especially in communities that have been developed. ${ }^{35}$

- Attribution authority.

Indroharto found on attribution occurred granting authority by a new government or created a new authority.

- Delegation authority

In the delegation there was a delegation of authority existing body or administrative positions States that have the authority to rule attributive to the entity or other state administrative positions, so a delegation is always preceded by the presence of an attribution of authority. ${ }^{36}$

- The authority's mandate

On the mandate was not discussed deliveries of authority, nor delegated, in terms of the mandate does not happen change authority whatsoever (at least in the sense of formal juridical), there is only the internal relations.

The terms of authority and the authority of the State Administrative Law there are differences in the views of some of the existing literature, conceptually term authority

\footnotetext{
${ }^{32}$ Agussalim Andi Gadjong, 2017, Pemerintahan Daerah Kajian Politik Hukum, Bogor Ghalia Indonesia, p. 95.

${ }^{33}$ According Asshiddiqie: In the concept of rule of law, idealized that which is supreme in the whole dynamic of national life is the law, not politics or economy. Jimly Asshiddiqie, 2017, Pokok-Pokok Hukum Tata Negara Indonesia Pasca Reformasi, Bhuana Ilmu Populer, Jakarta, p. 297

${ }^{34}$ Yuliandri, 2010, Asas-Asas Pembentukan Peraturan Perundang-Undangan Yang Baik Gagasan Pembentukan Undang-Undang Berkelanjutan, Pbl. 2, Raja Grafindo Persada, Jakarta, p. 249.

${ }^{35}$ Yuslim, 2014, the authority of the Governor as Vice Government In Government Management District / City According to the Constitution of 1945, Summary Dissertation, University of Andalas, Padang, p. 8.

${ }^{36}$ Indroharto, Usaha Memahami Undang-Undang Tentang Peradilan Tata Usaha Negara, Beberapa Pengertian Dasar Hukum Tata Usaha Negara, Buku I, Pustaka Sinar Harapan, Jakarta, p. 91.
} 
is often called authority, or jurisdiction and terms gezag referred to the competence or authority of bevoegdheid. ${ }^{37}$

\subsection{Theory Application of Authority}

The application of the law of his theory using the theory of authority, then when referring to the theory of "Stufenbau Des Rechts" by Hans Kelsen, the norms (including legal norms) it step-by-step and multi-layered meaning unity of norms is demonstrated by the fact that the establishment the norm that the more low-norms set by other, higher norms, which are determined by other norms making even higher and that regressus (a series of law-making process) is terminated by a basic norm of the highest, as the basis for the highest of the overall validity of the legal order, establish an order of this law. ${ }^{38}$

Hans Kelsen's theory also affects the legislation system in Indonesia, the MPR Decree No. XX / MPR / 1996 jo MPR No. III / MPR / 2000 jo Act No. 10 of 2004 jo Act No. 12 of 2011, concerning the Establishment of Legislation Article 7 (1), namely:

(1) Types and hierarchy of legislation consists of:

- 1945 Constitution (Constitution of the Republic of Indonesia of 1945);

- MPR (People's Consultative Assembly Decree);

- Law / Government Regulation (Law / Government Regulation in Lieu of law);

- PP (Government Regulation);

- Presidential Decree (Presidential Decree);

- Provincial Regulation (Provincial Regulation); and

- Regulation of the Regency / City.

Associated with the source of authority possessed by the notary and PPAT, As mentioned Ateng Syarifudin ${ }^{39}$ that the elements listed in the authority is 2, namely:

- The existence of formal authority;

- The power granted by law

\section{Closing}

\subsection{Conclusion}

Based on the research results can be concluded as follows:

- Based on the duties and authority of Notary asserted in UUJN, then Habib Adjie (2010: 78) divided into three areas of authority the public authority (Article 15 paragraph 1 UUJN), a special authority (Article 15 paragraph 2 UUJN), the authority which will be determined later (Article 15, paragraph 3 UUJN). The purpose of the public authority is authorized to make general deed-restricted as long as:

- Not excluded the other officials stipulated by law.

- Concerning the certificates must be made or authorized to make the authentic act on all deeds, agreements, and provisions required by law or desired by the person concerned.

\footnotetext{
${ }^{37}$ SF. Marbun, 2017, Peradilan Administrasi Negara dan Upaya Administrasi di Indonesia, Liberty, Yogyakarta, p. 153.

${ }^{38}$ Hans Kelsen, Teori Umum Tentang Hukum dan Negara, (Bandung: Nusa Media, 2014), p. 179.

39 Ateng Syafrudin, "Menuju Penyelenggaraan Pemerintahan Negara yang Bersih dan bertanggung jawab", Jurnal Pro Justisia Edition IV (2010): 22.
} 
Volume 6 Issue 3, September 2019

- Regarding the legal subject (person or entity) for the benefit of whom the deed was made or desired by the stakeholders (Habib Adjie: ibid).

- Referring to the basic theory of law that exist in the Results and discussion as well as the acquisition of authority, that the notary in a deed relating to land comes from legislation that is under the authority attribution means authorizing the new government by a provision in the legislation that is in terms of this is UUJN, so the authority obtained through attribution is a genuine authority.

\subsection{Suggestion}

- For candidate new notary candidate should understand exactly what the duties and authority of the notary in order not entangled problems or cases

- Before performing his duties, the notary in the compulsory first understand what authority and how the legal theory of authority to avoid confusion and in default in its implementation in the future. For the notary candidate is required to understand the theory of law and Notary Law in the notary office before serving as a notary.

\section{References}

[1] Abdul Rachmad Budiono, 2015. Pengantar I/mu Hukum, Bayumedia Publishing, Malang

[2] Agussalim Andi Gadjong, 2017, Pemerintahan Daerah Kajian Politik Hukum, Bogor Ghalia Indonesia.

[4] Djoko Soepadmo, 2014, Teknik Pembuatan Akta Seri B-1, PT.Bina Ilmu, Surabaya.

[5] I.P.M Ranuhandoko, 2009, Terminologi Hukum-Inggris Indonesia, Cetakan 5, Sinar Grafika, Jakarta.

[6] Habib Adjie, 2009, Hukum Notaris Indonesia (Tafsir Tematik Terhadap UndangUndang Jabatan Nomor 30 Tahun 2004 Tentang Jabatan Notaris, Cetakan 2, PT.Refika Aditama, Bandung.

[7] Habib Adjie, 2011, Kebatalan dan Pembatalan Akta Notaris, PT.Refika Aditama. Bandung.

[8] Habib Adjie, 2011, Kompilasi Peraturan Perundang-Undangan Jabatan Notaris, Pustaka Zaman, Semarang.

[9] Hans Kelsen, 2014, Teori Umum Tentang Hukum dan Negara, Bandung: Nusa Media.

[10] Husni Thamrin, 2011, Pembuatan Akta Pertanahan Oleh Notaris, Cetakan 2, Laksbang Pressindo, Yogyakarta.

[11] Indroharto, 2009, Usaha Memahami Undang-Undang Tentang Peradilan Tata Usaha Negara, Beberapa Pengertian Dasar Hukum Tata Usaha Negara, Buku I, Pustaka Sinar Harapan, Jakarta.

[12] Ira Koesoemawati dan Yunirman Rijan, 2009, Ke Notaris, Raih Asa Sukses (RAS), Jakarta.

[13] Komar Andasasmita, 2010, Notaris Selayang Pandang, Cet. 2, Bandung.

[14] Mulyoto, 2010, Kesalahan Notaris dalam Pembuatan Akta Perubahan Dasar CV, Cakrawala Media , Yogyakarta.

[15] Peter Mahmud Marzuki, 2010 Pengantar IImu Hukum, Kencana Pranada Media Group, Jakarta. 
[16] Prajudi Atmosudirjo, 2014, Hukum Administrasi Negara, Cetakan Kesepuluh, Ghalia Indonesia, Jakarta.

[17] R. Soegono Notodisoerjo, 2013, Hukum Notariat Di Indonesia Suatu Penjelasan, Cetakan 2, PT.Raja Grafindo Persada, Jakarta.

[18] R. Soegono Notodisoerjo, 2013, Hukum Notariat Di Indonesia Suatu Penjelasan, Cetakan 2, PT.Raja Grafindo Persada, Jakarta.

[19] R. Sugondo Notodisoerjo, 2013, Hukum Notariat di Indonesia, PT. Raja Grafindo, Jakarta.

[20] Santia Dewi dan R.M Fauwas Diradja, 2011, Panduan Teori dan Praktik Notaris, Pustaka Yustika, Yogyakarta.

[21] SF. Marbun, 2017, Peradilan Administrasi Negara dan Upaya Administrasi di Indonesia, Liberty, Yogyakarta.

[22] Yuliandri, 2010, Asas-Asas Pembentukan Peraturan Perundang-Undangan Yang Baik Gagasan Pembentukan Undang-Undang Berkelanjutan, Cet akan 2, Raja Grafindo Persada, Jakarta. 